\title{
Respiratory Complications after Laryngotracheal Separation
}

\author{
Tomohisa Hirai ${ }^{1)}$, Noriyuki Fukushima ${ }^{1)}$, Nobuyuki Miyahara ${ }^{1)}$ and Shin Masuda ${ }^{2)}$
}

We performed laryngotracheal separation (LTS) surgery in 27 patients with severe motor and intellectual disabilities (SMID) over a period of 8 years. Of these, seven developed serious respiratory complications after the operation. Herein, we present four of the cases with severe respiratory complications.

Case 1: A 9-year-old boy who developed severe breathing difficulty with tracheomalacia immediately after LTS: The condition was attributed to narrowing of the lumen of the trachea by the adjacent brachiocephalic artery. Brachiocephalic artery ligation was performed, which resulted in expansion of the lumen of the trachea.

Case 2: A 9-year-old boy who developed severe breathing difficulty with airway obstruction and difficulty in expectoration three years after the LTS operation: His level of consciousness decreased, which persists until date.

Case 3: A 9-year-old boy who developed severe airway obstruction with difficulty in expectoration four months after the LTS operation: He was in deep coma on arrival, and died of heart failure six months later.

Case 4: A 5-year-old girl who developed pneumonia due to respiratory syncytial virus infection: she died sixteen 16 days later.

We need to modify the operating technique of LTS in cases with a distance of less than $20 \mathrm{~mm}$ between the back of the sternum and the anterior aspect of the vertebral body. In such cases, it is desirable to avoid lifting the trachea that may cause narrowing of the tracheal lumen by the adjacent brachiocephalic artery.

Thus, LTS surgery may result in serious respiratory complications, e.g., airway obstruction with difficulty in expectoration and severe pneumonia.

Sufficient explanation about the risk of respiratory complications must be provided to the family and caregiver prior to undertaking LTS surgery. Furthermore, after LTS surgery, multiple approaches to respiratory care, including chest physiotherapy and breathing exercises are necessary.

Keywords : respiratory complications, laryngotracheal separation, severe motor and intellectual disabilities, narrowing lumen of trachea, airway obstruction

\section{References}

1）清水 賢, 林田哲郎, 渡辺剛士, 他：重度の罯下障害例に 対する喉頭気管分離術手術症例 106 例の検討. 日摂食嚥下 リ八会誌 2: 29-35, 1998 .

2）飯田英基，安岡義人，二宮 洋，他：喉頭気管分離術後の QOL に関するアンケート調查報告. 小児耳鼻 32：113-118, 2011.

3）前田健一, 横井暁子, 中尾 真, 他：気管切開術施行後の 重症心身障害児に対する喉頭気管分離術の検討．小児外科 43: 288-291, 2011.

4）高見澤滋, 西島栄治, 津川 力, 他 : 喉頭気管分離術後の 合併症と再手術。小児外科 37：1041-1046, 2005.

5）小河原昇, 高松一郎, 陰里ゆらみ, 他 : 若年者の難治性誤 嚥に対する喉頭気管分離・気管食道吻合術および喉頭気管 分離術の検討。日気管食道会報 47：463-468, 1996.

6) Montgomery WW : Surgery to prevent aspiration. Arch Otolarygol 101: 679-682, 1975.

7) Hirai T, Fukushima N, Ono K, et al. : Experience with laryngotracheal separation at Hiroshima Prefectural Hospital. Pract Otol (Kyoto) 100: 61-64, 2007.

8）佐藤英章, 古田繁行, 島 秀樹, 他: 当院における喉頭気 管分離術後気管腕頭動脈瘻への治療戦略. 小児外科 43 :

1) Department of Otorhinolaryngology, Head and Neck Surgery, Hiroshima Prefectural Hospital

Corresponding Author Address : Tomohisa Hirai

t-hirai@hph.pref.hiroshima.jp

2) Department of Pediatric Rehabilitation, Hiroshima Prefectural Hospital 
946-950, 2011.

9）長江秀樹，福本弘二，福澤宏明，他：喉頭気管分離術と気 管腕頭動脈瘻一その予防と対策一. 小児外科 43：293-296, 2011.

10) Fukumoto K, Urushihara N, Fukuzawa H, et al. : Laryngotracheal separation using skin flap formation: a novel surgical procedure. Pediatr Surg Int 27: 67-71, 2011.

11）安岡義人, 二宮 洋, 紫野正人：喉頭気管分離術（気管弁 法）の術式とその利点. 小児外科 43: 283-287, 2011.

12）鹿野真人, 桑畑直史, 高取 隆, 他：長期臥床症例に対す る輪状軟骨鉗除を併用する声門閉鎖術。喉頭 20：5-12,
2008.

13）那須 隆，小池修治，鹿野真人，他：声門閉鎖術を施行し た超重度心身障害児の 5 例の検討. 喉頭 24：116-119, 2012.

14）渡部潤一，楠 孝文，寺本直史，他：慢性呼吸不全を呈す る重症心身障害児の呼吸理学療法一複合的なアプローチに よる呼吸機能の検討一。小児内科 42: 341-344, 2010.

15）堤 裕幸：ハイリスク児の RS ウイルス感染予防の進歩. 化 療の領域 19: 1597-1601, 2003.

16）河島尚志，五百井寬明：重症 RS ウイルス感染症．化療の 領域 24：1473-1480, 2008.

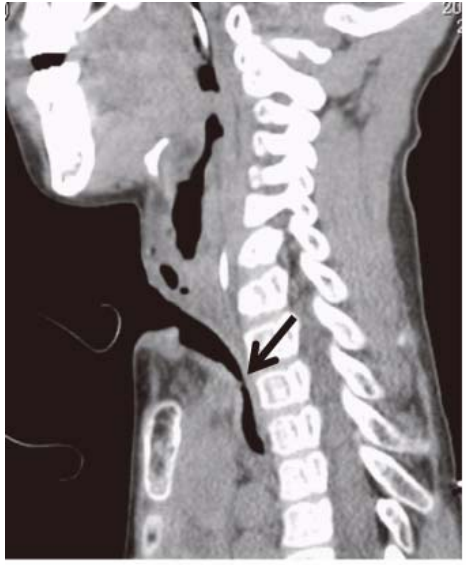

a

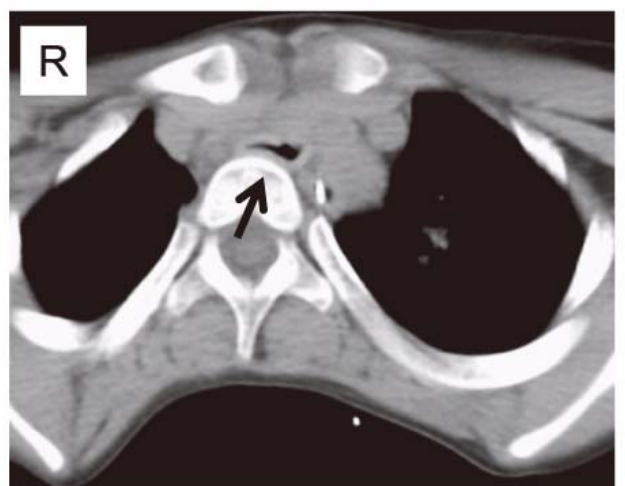

b

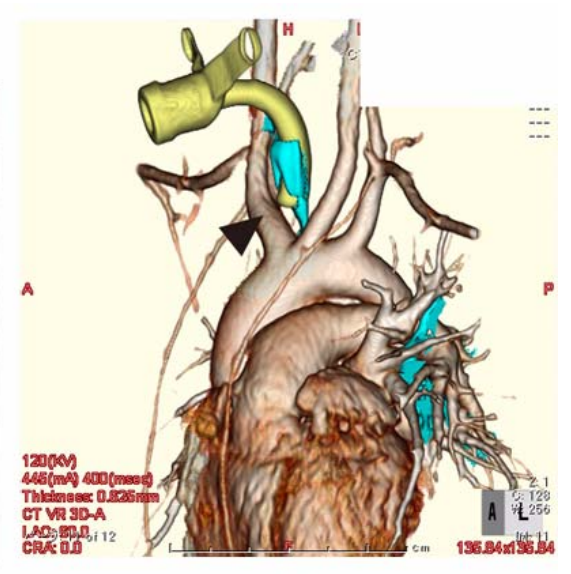

C

The CT findings of case 1 (a : sagittal findings, $\mathrm{b}$ : axial findings, $\mathrm{c}: 3$-D CT findings)

Tracheomalacia was attributed to narrowing of the lumen of the trachea by the adjacent brachiocephalic artery.

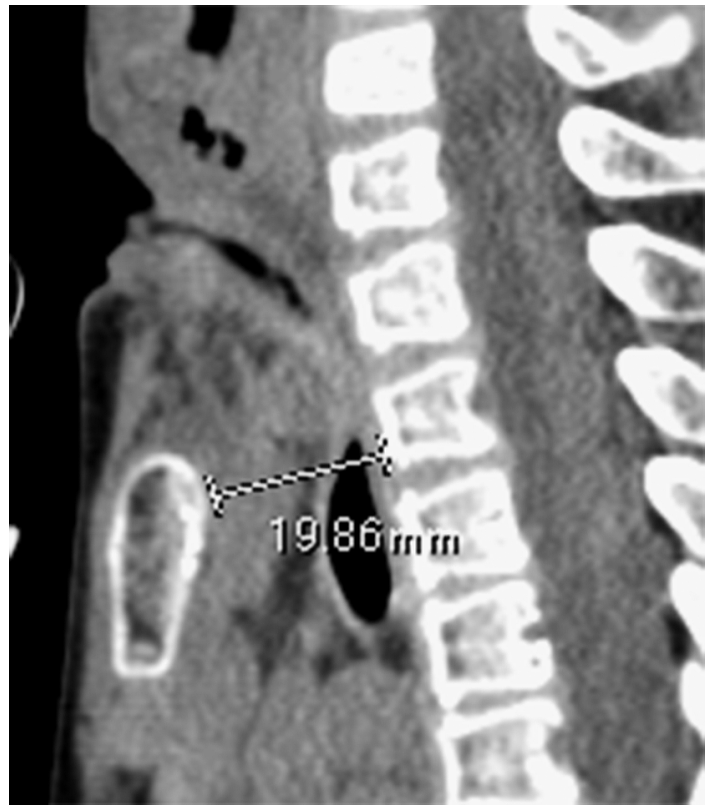

The CT findings of case 1 ; sagittal findings, postoperation.

The distance between the back of the sternum and the anterior aspect of the vertebral body is less than $20 \mathrm{~mm}$. 